\title{
Coordination and Collaboration Functions of Disaster Management Centers for Humanitarian Logistics: A Case Study at Merapi Eruption
}

\author{
Naniek Utami Handayani ${ }^{1 *}$, Anita Mustikasari ${ }^{1}$ \\ Department of Industrial Engineering, Faculty of Engineering, Diponegoro University, Semarang, \\ Indonesia 50275
}

\begin{abstract}
Although the humanitarian logistics coordination model in Indonesia is fairly effective, the role of each player remains unclear. For example, some of the activities that are sufficient to be done by one agency are in fact done by other institutions as well. This has resulted in inefficiency and ineffectiveness regarding on the handling of disaster relief goods. Therefore, it is essential to determine the role of each stakeholder involved in the management of natural disasters in order to improve the model. This study was conducted to provide the proposed model of humanitarian logistics coordination for developing the framework of coordination between stakeholders in the management of natural disasters, with the involvement of logistics players through the RASIC Chart method.
\end{abstract}

\section{Introduction}

Disaster is a term that refers to a physical disorder that affects the system as a whole and threatens its priorities and goals [1,2]. The importance of disaster management should encourage the successful implementation of an emergency response effort that starts with strategic planning [2,3]. Disaster response is generally composed of four phases [4], namely mitigation, preparation, response, and recovery.

Indonesia is one of the countries located in the disaster zone. The requirement of an integrated natural disaster management system is satisfied by the disaster logistics management system. Logistics management of disasters requires support via information about the needs of humanitarian goods, a system that is able to quickly provide the information needs of victims, the distribution of the sacrificial site, and listing the logistics needs of disaster victims at the scene of the disaster as well at any evacuation point. In order to improve the performance of natural disaster relief operations, logistics and inventory management activities are necessary. The role of logistics systems is to provide the necessary relief items quickly and efficiently. Though the humanitarian logistics coordination model in Indonesia is fairly effective, the role of each player remains unclear. Coordination among relief agencies is an important aspect to be noted. Lack of coordination and cooperation among humanitarian agencies is one of the obstacles in humanitarian logistics [5]. Coordination and cooperation among organizations prevents

* Corresponding author: naniekh@gmail.com 
huge losses in terms of resources and materials [6]. Coordination problems also occur in the handling of natural disasters in Indonesia. Currently, the management of natural disaster emergency responses involves the Disaster Mitigation Agency (BPBD), the Department of Social Services, Indonesian Army, Department of Public Works, Department of Health Services, Indonesian Red Cross, Department of Communication and Informatics, Department of Finance, Department of Education, Head District, SAR, NGOs, Indonesian Agency for Meteorological, Climatological and Geophysics, and volunteers. The model of collaboration and coordination between the stakeholders still has some drawbacks, such as emergency responses that do not involve those who are competent in the field of logistics.

This study was conducted to provide the proposed model of humanitarian logistics coordination for developing the framework of coordination between stakeholders in the management of natural disasters, with the involvement of logistics players. This framework is expected to be a reference in establishing the involvement of stakeholders and the roles of each party to improve the effectiveness and efficiency of the management of natural disasters. In this paper, deductive methods are used to map stakeholders which are tied to disaster management and clarified through the RASIC Chart.

\section{Research Method}

A RASIC Chart will be used in this research. It has functions for recognizing the rules and competences of each humanitarian logistics stakeholder in Indonesia in a process that ensures that ownership, approval, support, consultation, and communication responsibilities are assigned [6]. The advantages of a RASIC chart is ensuring an obvious relationship between activities and resources, emphasizing distinct competences for every resource, and providing suggestions for communication planning [7]. Responsible represents the stakeholders who are responsible for accomplishing the activity, while approves represents the stakeholders who have authority to take an action. Support means the stakeholders who offer resources. Stakeholders who have to know the outcome of the implementation of the activities are referred to as informed. Finally, consulted refers to stakeholders who adopt the implementation suggestions indirectly [8]. A RASIC chart will ensure stakeholders that are required to know do indeed know and stakeholders who are not required to know will not [9]. Data are compiled by interviewing and surveys about coordination among the Department of Social Services, Indonesian Army, Department of Public Works, Department of Health Services, Indonesian Red Cross, Department of Communication and Informatics, Department of Finance, Department of Education, Head District, SAR, NGOs, Indonesian Agency for Meteorology, Climatology and Geophysics, and volunteers through the BPBD Magelang branch.

\section{Results and Analysis}

\subsection{Job Analysis of Each Stakeholder in Humanitarian Logistics}

In order to improve the humanitarian logistics system in Merapi Eruption, it is better to begin by defining all the stakeholders of the system and also assessing their consciousness level regarding a natural disaster threat. For instance, the BPBD is defined as a government stakeholder, who has coordinator, practitioner and commander functions in disaster management and emergency. The coordination function of the BPBD involves it coordinating with all stakeholders in case there is no disaster. The BPBD uses its practitioner function when a minor disaster occurs, for instance a landslide in which one or two houses are damaged. When there is a major disaster, the BPBD has the function as 
commander to coordinate and collaborate with all stakeholders. The scope of the BPBD includes mitigation, preparedness, response, and recovery. The Department of Social Services is obliged to organize, provide technical guidance, and supervise the enforcement of the mitigation, preparedness, response, and recovery activities for natural disaster victims. The Indonesian Army/Police has the functions of helping the BPBD throughout the technical process with SAR in evacuate victims. The Department of Public Works has the responsibility for constructing infrastructure for access during and post disasters. The Department of Health Services focuses on handling the health factors of disaster risk management by providing medicines and medical personnel in disasters. Meanwhile, the Indonesia Red Cross has the responsibility of helping SAR and the Department of Health Services give first aid to disaster victims such as blood transfusion. The Department of Communication and Informatics has the responsibility of providing information during disaster while the Department of Finance has authority over issues of budget costs in all processes of the disasters phase. The Department of Education supports the education of people in disaster risk management. The Indonesian Agency for Meteorology, Climatology and Geophysics has the responsibility for providing information related to disaster risk including affected potential areas, while Head of District work in managing the logistics center and people during the disaster phase. NGOs and volunteers, being Non-Government institutions, supports all the stakeholders related to disaster risk management. All the stakeholders of the Humanitarian Logistics system should in particular have a similar level of awareness and involvement concerning the system and its capabilities. Learning and training play a vital role in order to create a disaster resilient community with an effective emergency management system, by helping to increase the community awareness. The cluster concept is another key factor that forms part of improving the operational effectiveness of an emergency management system. Clusters can be extremely helpful in establishing the lacking coordination between different actors of the emergency system in Merapi Eruption.

A RASIC chart is used for representing the role of each stakeholder concerning humanitarian logistics in Indonesia according to the four phases on disaster risk management: mitigation, preparedness, response, and recovery. The mitigation phase is an essential activity for local governments to identify and coordinate efforts of stakeholders to reduce and eliminate risks associated with disasters. The preparedness phase includes evolving urgency procedures and stakeholder competence to ensure an effective and efficient response that tackles the impacts of a disaster. The primary objective of an effective response to a disaster is rescuing people and reducing damage so that aid is provided during or immediately following a disaster in order to care for the people affected. The recovery phase consists of rehabilitation in a short period and reconstruction in a long period, with the purpose of repairing important support systems and restoring life back to normal. The measurement indicators of disaster risk management phases are shown in Table 1 and were adopted from [10].

In the mitigation phases, BPBD has a function as coordinator of all stakeholders. The Department of Finance has the functions of analyzing and giving approval to all measurement indicators, which includes the budget cost. In addition, developing a master plan for disaster risk management and mitigation is supported by all stakeholders excluding Head District. Head District only gets result information from BPDB. While, developing a master plan for disaster risk management become measurement indicator that supported by almost all stakeholders except Dept. of Communication and Informatics as approves and District Head as informed. 
Table 1. RASIC Chart on The Mitigation Phase

\begin{tabular}{|c|c|c|c|c|c|c|c|c|c|c|c|c|c|c|c|}
\hline $\begin{array}{l}\text { R-Responsible } \\
\text { A-Approves } \\
\text { S-Supports } \\
\text { I-Informed } \\
\text { C-Consulted } \\
\text { NA-Not Available }\end{array}$ & 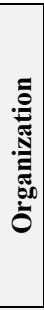 & 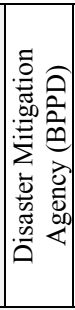 & 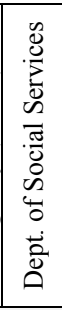 & 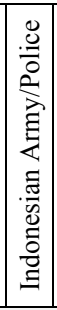 & 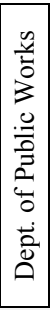 & 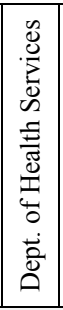 & 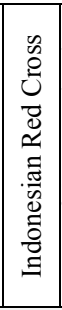 & 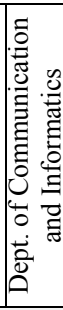 & 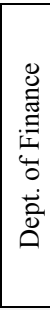 & 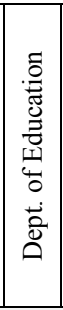 & 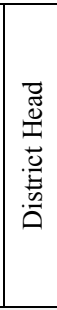 & 先 & $\begin{array}{l}2 \\
0 \\
0 \\
z\end{array}$ & 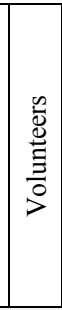 & 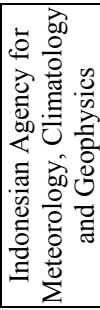 \\
\hline Measurement Indicators & \multicolumn{15}{|c|}{ Mitigation Phase } \\
\hline $\begin{array}{l}\text { Training and education on } \\
\text { disaster risk management }\end{array}$ & & $\mathrm{R}$ & $\mathrm{S}$ & I & $\mathrm{NA}$ & NA & NA & I & A & $\mathrm{S}$ & $\mathrm{R}$ & $\mathrm{R}$ & $\mathrm{C}$ & $\mathrm{S}$ & $\mathrm{R}$ \\
\hline $\begin{array}{l}\text { Analyzing risks to measure the } \\
\text { potential areas for disasters }\end{array}$ & & $\mathrm{R}$ & I & $\mathrm{NA}$ & I & NA & NA & NA & A & NA & $\mathrm{R}$ & NA & C & NA & $\mathrm{R}$ \\
\hline Zoning and land use controls & & $\mathrm{R}$ & NA & $\mathrm{NA}$ & $\mathrm{R}$ & NA & NA & NA & NA & NA & $\mathrm{R}$ & NA & NA & NA & $\mathrm{R}$ \\
\hline $\begin{array}{l}\text { Insuring roads and bridges to } \\
\text { reduce the financial impacts of } \\
\text { disasters }\end{array}$ & & NA & NA & $\mathrm{NA}$ & S & NA & NA & NA & A & NA & NA & NA & NA & NA & NA \\
\hline $\begin{array}{l}\text { Developing a master plan for } \\
\text { disaster risk management }\end{array}$ & & $\mathrm{R}$ & $\mathrm{S}$ & $\mathrm{S}$ & $\mathrm{S}$ & $\mathrm{S}$ & $\mathrm{S}$ & $\mathrm{S}$ & A & $\mathrm{S}$ & I & $\mathrm{S}$ & $\mathrm{S}$ & $\mathrm{S}$ & $\mathrm{S}$ \\
\hline $\begin{array}{lcr}\text { Developing } & \text { disaster } & \text { risk } \\
\text { management information } & \text { system } \\
\end{array}$ & & $\mathrm{R}$ & $\mathrm{S}$ & $\mathrm{NA}$ & $\mathrm{NA}$ & NA & $\mathrm{S}$ & $\mathrm{R}$ & NA & NA & NA & NA & $\mathrm{S}$ & $\mathrm{S}$ & NA \\
\hline $\begin{array}{l}\text { Developing engineering design } \\
\text { standards for resilient roads and } \\
\text { bridges }\end{array}$ & & $\mathrm{R}$ & $\mathrm{S}$ & $\mathrm{S}$ & $\mathrm{R}$ & NA & NA & NA & A & NA & I & NA & NA & NA & NA \\
\hline $\begin{array}{l}\text { Providing timely and effective } \\
\text { information related to disaster } \\
\text { risk }\end{array}$ & & $\mathrm{R}$ & $\mathrm{S}$ & $\mathrm{NA}$ & $\mathrm{NA}$ & NA & $\mathrm{S}$ & $\mathrm{R}$ & NA & NA & $\mathrm{S}$ & NA & NA & NA & $\mathrm{R}$ \\
\hline $\begin{array}{l}\text { Constructing retarding basins, } \\
\text { barriers, culverts, levees, and } \\
\text { drainage }\end{array}$ & & $\mathrm{R}$ & NA & S & $\mathrm{R}$ & NA & NA & NA & A & NA & I & NA & NA & NA & NA \\
\hline
\end{tabular}

The preparedness phases as shown on Table 2, the BPBD has a coordinator function in almost all of the measurement indicators excluding the developing strategies for public education which the Department of Education is responsible for. As regards all measurement indicators for the preparedness phases, the BPBD and the Department of Social Services work on them for developing disaster emergency management systems, budgeting and maintaining disaster emergency supplies, and conducting risk management exercises to train personnel and test capabilities.

In the response phase, several measurement indicators are analyzed using RASIC Chart. Activating the disaster emergency operations plans and operations centers and evacuating threatened populations and vehicles be the responsibly of Indonesian Army, Indonesian Red Cross and SAR. Operating shelters and provision of mass care are supported by Indonesian Army, Dept. of Health Services and Indonesian Red Cross and be the responsibly of BPPD, Dept. of Social Services, District Head, NGOs and Volunteers. Estimating economic damage is only the responsibly of BPBD. While Dept. of Finance only approves regarding on budget cost. BPBD and Dept. of Social Services also be responsible on establishing procedures to prevent and suppress secondary hazards, documenting lessons learned and best practices, and implementing effective logistics management. Dept. of Education, NGOs, and Volunteers merely support it. Implementing effective coordination with other stakeholders and providing information on disasteraffected areas to public be the responsibly of BPBD and Dept. of Communications and Information supported by District Head. 
In the recovery phase, almost all of measurement indicators be the responsibly of Dept. of Public Work. Those measurement indicators are considering sustainability in postdisaster reconstruction, shortening reconstruction time by applying quick mobilization, selecting reconstruction contractors earlier, constructing temporary roads and bridges, implementing execution plan for post-disaster reconstruction, applying lean construction in post-disaster reconstruction, realigning roads and relocating bridges to lower disaster hazard locations, and acquiring stakeholders' approval on reconstruction projects. Cleaning disaster debris and documenting lessons learned and best practices be the responsibly of BPBD supported by Volunteers and Dept. of Education. While, the function of Dept. of Finance in this phase is remain the same as the previous phase, that is concerning in approval of budget cost.

Table 2. RASIC Chart on The Preparedness Phase

\begin{tabular}{|c|c|c|c|c|c|c|c|c|c|c|c|c|c|c|c|}
\hline $\begin{array}{l}\text { R-Responsible } \\
\text { A-Approves } \\
\text { S-Supports } \\
\text { I-Informed } \\
\text { C-Consulted } \\
\text { NA-Not Available }\end{array}$ & 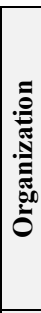 & 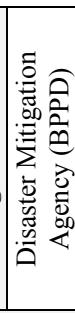 & 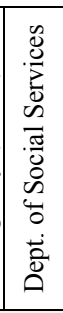 & 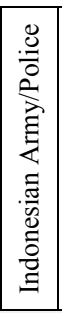 & 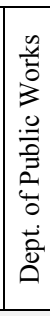 & 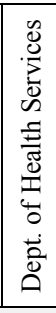 & 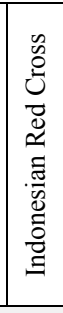 & 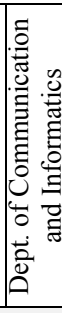 & 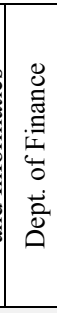 & 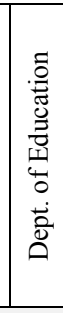 & 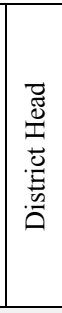 & 妾 & $\begin{array}{l}2 \\
\text { O } \\
\text { Z }\end{array}$ & 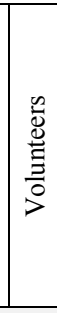 & 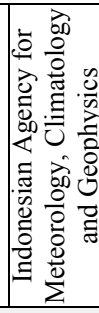 \\
\hline Measurement Indicators & & & & & & & Prepa & aredn & ess $P$ & Phase & & & & & \\
\hline $\begin{array}{l}\text { Recruiting personnel for disaster } \\
\text { emergency services }\end{array}$ & & $\mathrm{R}$ & NA & $\mathrm{R}$ & NA & NA & $\mathrm{R}$ & NA & NA & NA & NA & $\mathrm{S}$ & $\mathrm{S}$ & $\mathrm{R}$ & NA \\
\hline $\begin{array}{l}\text { Developing disaster emergency } \\
\text { management systems }\end{array}$ & & $\mathrm{R}$ & $\mathrm{R}$ & NA & NA & NA & NA & NA & NA & NA & NA & NA & NA & NA & NA \\
\hline $\begin{array}{l}\text { Developing strategies for public } \\
\text { education }\end{array}$ & & NA & $\mathrm{R}$ & NA & NA & NA & $\mathrm{R}$ & $\mathrm{R}$ & NA & $\mathrm{R}$ & NA & NA & $\mathrm{S}$ & $\mathrm{S}$ & NA \\
\hline $\begin{array}{lcc}\begin{array}{l}\text { Budgeting } \\
\text { emergency equipment }\end{array} & \text { disaster } \\
\end{array}$ & & $\mathrm{R}$ & $\mathrm{S}$ & NA & NA & NA & NA & NA & A & NA & NA & NA & NA & NA & NA \\
\hline $\begin{array}{l}\text { Maintaining disaster emergency } \\
\text { supplies }\end{array}$ & & $\mathrm{R}$ & $\mathrm{R}$ & NA & NA & NA & NA & NA & NA & NA & NA & NA & NA & NA & NA \\
\hline $\begin{array}{l}\text { Locating places for emergency } \\
\text { operation centers }\end{array}$ & & $\mathrm{R}$ & $\mathrm{S}$ & $\mathrm{S}$ & $\mathrm{S}$ & $\mathrm{S}$ & $\mathrm{S}$ & $\mathrm{S}$ & A & $\mathrm{S}$ & $\mathrm{R}$ & $\mathrm{S}$ & $\mathrm{S}$ & $\mathrm{S}$ & $\mathrm{S}$ \\
\hline $\begin{array}{l}\text { Developing prediction and } \\
\text { warning communications }\end{array}$ & & $\mathrm{S}$ & NA & NA & NA & NA & NA & $\mathrm{S}$ & NA & NA & $\mathrm{S}$ & NA & NA & NA & $\mathrm{R}$ \\
\hline $\begin{array}{l}\text { Conducting risk management } \\
\text { exercises to train personnel and } \\
\text { test capabilities }\end{array}$ & & $\mathrm{R}$ & $\mathrm{R}$ & $\mathrm{R}$ & NA & NA & $\mathrm{R}$ & NA & NA & NA & NA & $\mathrm{R}$ & $\mathrm{S}$ & $\mathrm{R}$ & NA \\
\hline $\begin{array}{l}\text { Using technology to identify and } \\
\text { assess disasters, and damaged } \\
\text { facilities }\end{array}$ & & $\mathrm{S}$ & NA & NA & NA & NA & NA & NA & NA & NA & NA & NA & NA & NA & $\mathrm{R}$ \\
\hline $\begin{array}{l}\text { Developing coordination } \\
\text { procedures with stakeholders }\end{array}$ & & $\mathrm{R}$ & NA & S & NA & NA & $S$ & $\mathrm{R}$ & NA & NA & $\mathrm{S}$ & $\mathrm{S}$ & $S$ & $\mathrm{~S}$ & NA \\
\hline
\end{tabular}

\subsection{Merapi Eruption Coordination Model for Humanitarian Logistics}

According to an interview with BPBD and the Magelang and literature review [11], the success factors of humanitarian logistics management can divided into three variables, i.e., strategical, tactical, and operational. Each variable has several indicators. Strategical i.e., sustainability, cooperation, networking, standardization aids logistics, safety, independence and fairness, caring. Tactical, i.e., coordination, collaboration, involvement of stakeholders, assessment and planning, management of humanitarian aids logistics, inventory management. Operational, i.e., quick response, flexibility, efficiency of management of 
humanitarian aids logistics, availability of disaster relief goods, and availability of volunteers.

On the operational level - the coordination and collaboration on management of natural disasters - Merapi Eruption has worked well, but there is still a lack of disaster relief management by any stakeholders involved. This needs to be supported with supervision in the location, so that relief goods can be channeled more effectively and efficiently. Coordination on disaster relief management needs to be supported by the existing information systems being up to date regarding the living layout of the recipients of the relief goods, the barracks, the number of refugee needs, availability of goods, and how to distribute the goods. The manual coordination which is currently done has led to slow responses in handling victims so the coordination process should be supported by an integrated information system.

\section{Conclusions}

Concerning humanitarian logistic systems in Merapi Eruption involves certain institutions. The BPBD acts as a coordinator for the functions of the mitigation and preparedness phase, as practitioner in response phase, and as a commander in the recovery phase. The Department of Social Services has the responsibility of helping the BPBD in the mitigation and preparedness phase. Meanwhile the Department of Public Works contributes in the recovery phase as practitioners in all activities related to restoration and construction post disaster. Regarding budgeting costs, funding can be secured by any stakeholder under the supervision of the Department of Finance. Besides that, the significant stakeholder who works on the mitigation phase is the Indonesian Agency for Meteorology, Climatology and Geophysics. It is also concluded that there are several stakeholders who do not contribute much directly in disaster risk management such as the Department of Education. A RASIC chart is a method for analyzing the role of stakeholders involved in disaster relief and for indicating the relationships among them in terms of humanitarian logistics in Indonesia. In this research, we demonstrated the primary model for this using the case of Merapi Eruption and analyzed the roles and relationships of each stakeholder, considering their major responsibility. For next research, it is suggested that work is done on integrating an information system between each stakeholder to establish a better humanitarian logistic system in Indonesia.

\section{References}

1. L. Van Wassenhove, J. Oper. Res. Soc. 57, 5 (2006)

2. A. Cozzolino, SSBM (2012)

3. R. Tomasini, L. Van Wassenhove, and L. Van Wassenhove, SPRINGER (2009)

4. G. O'Brien, P. O'Keefe, Z. Gadema, J. Swords, Int. J. 19, 498-508 (2010)

5. A. Thomas, L.R. Kopczak, FHI (2005)

6. R. Kaynak, A.T. Tuğer, Procd. Soc. Behv. 109, 432-437 (2014)

7. R.D. Reid, Qual. Prog. 38, 11 (2005)

8. T. Octavia, I. G. A Widyadana, H. C. Palit, Springer Singap. (2016)

9. R. D. Reid, Qual. Prog. 36, 4 (2003)

10. M. Mojtahedi, B. L. Oo. Int. J. Disas. Risk Re. 21, 35-43 (2017)

11. H. Abidi, S. Leeuw, M. Klump, Int. J. Bus. Manag. Invent. (2013) 